\title{
Porin from the Outer Membrane of Escherichia coli: Immunological Characterization of Native and Heat-dissociated Forms
}

\author{
By HARMEN HOFSTRA* AND JACOB DANKERT \\ Laboratory for Medical Microbiology and Department of Hospital Infections, University \\ Hospital, Oostersingel 59, 9713 EZ Groningen, The Netherlands
}

(Received 30 October 1980; revised 21 December 1980)

\begin{abstract}
Antisera against porin oligomers isolated from the outer membrane of Escherichia coli $\mathrm{O} 26 \mathrm{~K} 60$ and against porin monomers from the same bacterial strain were elicited in rabbits by intramuscular administration with Freund's complete adjuvant. Antibodies against native porin oligomers reacted strongly with porin oligomers, as revealed by sodium dodecyl sulphate-polyacrylamide gel immunoperoxidase (SGIP) analysis, the enzyme-linked immunosorbent assay (ELISA) and immunodiffusion, but showed no significant reaction with denatured monomers. The antibodies were completely absorbed by the intact outer membrane-peptidoglycan complex, which suggests that they were directed against antigenic determinants expressed on the outside of the intact outer membrane. Antibodies directed against denatured porin monomers reacted strongly with monomers in all tests but reacted only very weakly with porin oligomers. They were not absorbed by the native porin situated in the intact outer membrane. This indicates that the major antigenic determinants of the denatured porin monomer are hardly related to those of the native trimer situated in the intact outer membrane. The antigenic determinants of the denatured monomer seem to becume fully expressed only after dissociation and denaturation of the porin. It is concluded that the immunological relationship of denatured porin monomers derived from many strains of $E$. coli and other Enterobacteriaceae which was reported in previous studies may not indicate that native porin trimers of these strains are also related.
\end{abstract}

\section{INTRODUCTION}

The cell envelope of the Enterobacteriaceae consists of a cytoplasmic membrane, a peptidoglycan layer and an outer membrane (OM). The OM acts as a permeability barrier, allowing the passage of sugars and other hydrophilic molecules with molecular weights up to 600 (Nakae \& Nikaido, 1975; Decad \& Nikaido, 1976). This passive transport function is mediated by transmembrane proteins, porins (Nakae, 1976a), which form permeability channels through the OM (Benz et al., 1978; Nakae, 1976b). These proteins are identical to the matrix protein (Rosenbusch, 1974), proteins b and c (Lugtenberg et al., 1975) (now designated ompF and ompC proteins after their structural genes) in Escherichia coli $\mathrm{K} 12$ and the $34 \mathrm{~K}, 35 \mathrm{~K}$ and $36 \mathrm{~K}$ proteins of Salmonella typhimurium LT2 (Nakae, $1976 \mathrm{~b}$ ).

Pore proteins are non-covalently associated with the peptidoglycan (Rosenbusch, 1974; Hasegawa et al., 1976), while their exposure on the outer surface of the bacterium is evidenced by their role as phage receptors (Datta et al., 1977; Verhoef et al., 1977). Porins can be extracted from the OM-peptidoglycan complex either by heating at $100^{\circ} \mathrm{C}$ in sodium dodecyl sulphate (SDS) solution (Rosenbusch, 1974) or at $37^{\circ} \mathrm{C}$ in SDS-containing buffer supplemented with $0.5 \mathrm{M}-\mathrm{NaCl}$ (Nakamura \& Mizushima, 1976). By the former method porin monomers are obtained, with molecular weights of about 35000 . The latter procedure does not cause denaturation and yields predominantly oligomers, which are mainly trimers 
(Nakamura \& Mizushima, 1976; Nakae et al., 1979). Cross-linking experiments (Palva \& Randall, 1978) and sedimentation equilibrium studies (Nakae et al., 1979) indicated that the basic unit of the porins in the enterobacterial $\mathrm{OM}$ is also a trimer.

Heat-dissociated pore proteins (porin monomers) derived from many members of Enterobacteriaceae have been shown to be immunologically cross-reacting (Hofstra \& Dankert, 1980b, $c$; Hofstra et al., 1980), which indicates that their structure has been well conserved during evolution. However, we have observed that antibodies against heatdissociated porin were hardly absorbed at all by intact OM preparations; in contrast

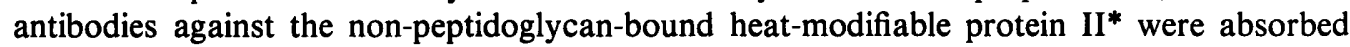
well (Hofstra \& Dankert, $1980 a$ ). We suspected that denaturation of the pore protein by heat and SDS could be the reason why antibodies against porin monomers were not absorbed in these experiments.

In the present study we report the results of an immunochemical investigation of the major pore protein of $E$. coli $\mathrm{O} 26 \mathrm{~K} 60$. We present evidence that oligomers and monomers of the same porin differ in their antigenic structure and behave like practically unrelated antigens.

\section{METHODS}

Bacterial strain, growth conditions and isolation of the outer membrane. Escherichia coli serotype $026 \mathrm{~K} 60$ was maintained and grown as described previously (Dankert \& Hofstra, 1978). The OM-peptidoglycan complex was obtained by Triton X-100 extraction of a crude envelope fraction according to Schnaitman (1971) as previously described in detail (Dankert \& Hofstra, 1978).

Isolation and purification of protein I (porin). The OM-peptidoglycan complex was extracted with $50 \mathrm{ml}$ $0.01 \mathrm{M}$-Tris/HCl buffer ( $\mathrm{pH} 7.3$ ) containing $2 \%(\mathrm{w} / \mathrm{v})$ SDS supplemented with $0.01 \%(\mathrm{v} / \mathrm{v})$ 2-mercaptoethanol and $10 \%(\mathrm{v} / \mathrm{v})$ glycerol for $30 \mathrm{~min}$ at $50^{\circ} \mathrm{C}$, essentially according to Rosenbusch (1974), in order to remove non-peptidoglycan-associated proteins. The insoluble material was harvested by ultracentrifugation $(100000 \mathrm{~g}$, 45 min, $16^{\circ} \mathrm{C}$; Hereaus, Osterode, F.R.G.) and again extracted with the same buffer to remove any traces of non-peptidoglycan-bound proteins. The resulting porin-peptidoglycan complex was washed once with demineralized water. About half of the porin-peptidoglycan preparation thus obtained was extracted with SDS-containing buffer at $100^{\circ} \mathrm{C}$, followed by repeated column chromatography of the extracted porin monomers on Biogel P-150 (Bio-Rad) as previously described in detail (Hofstra \& Dankert, 1980a).

A porin preparation in a configuration more closely resembling the native state (native porin oligomers) was obtained by extracting the remainder of the porin-peptidoglycan complex with SDS-containing buffer supplemented with $0.5 \mathrm{M}-\mathrm{NaCl}$ at $37^{\circ} \mathrm{C}$ as described by Nakamura \& Mizushima (1976). Insoluble material was sedimented by ultracentrifugation $\left(130000 \mathrm{~g}, 60 \mathrm{~min}, 20^{\circ} \mathrm{C}\right)$. The supernatant containing native porin was then fractionated by sucrose gradient centrifugation, essentially according to Palva \& Randall (1978), on a 5-35\% $(\mathrm{w} / \mathrm{v})$ sucrose gradient in $0.05 \mathrm{M}$-Tris/ $\mathrm{HCl}(\mathrm{pH} 7.4)$ containing $0.2 \%$ (w/v) SDS. After centrifugation $(180000 \mathrm{~g}$, $18 \mathrm{~h}, 16^{\circ} \mathrm{C}$ ) the total gradient was divided into 20 fractions of about $1 \mathrm{ml}$ each. From each fraction $20 \mu \mathrm{l}$ samples were taken for analysis by SDS-polyacrylamide gel electrophoresis (SDS-PAGE) according to Laemmli (1970) both without further treatment and after heating at $100^{\circ} \mathrm{C}$ for $5 \mathrm{~min}$. Fractions showing the presence of only porin trimers (visualized as a single 100000 molecular weight band in the SDS-PAGE profile of untreated samples or a 36000 molecular weight monomer band after heating at $100^{\circ} \mathrm{C}$ ) were pooled, dialysed against demineralized water (overnight, room temperature) and lyophilized (Edwards, Crawley, Sussex).

Isolation of other envelope constituents. Lipopolysaccharide (LPS) of E. coli $026 \mathrm{~K} 60$ was isolated by phenol/water extraction as described previously (Hofstra \& Dankert, 1979). The murein-lipoprotein complex of this strain was isolated as described previously (Hofstra \& Dankert, 1980a). Free lipoprotein, isolated from OM of $E$ coli $\mathrm{J} 5$ according to Inouye et al. (1976), was generously donated by J. Wensinck (Laboratory for Biochemistry, Groningen, The Netherlands).

Antisera. Antisera against native porin oligomers, denatured porin monomers and murein-lipoprotein were raised in rabbits by intramuscular administration of the antigens suspended to a concentration of $1 \mathrm{mg} \mathrm{ml}^{-1}$ in $0.9 \%(\mathrm{w} / \mathrm{v}) \mathrm{NaCl}$ with Freund's complete adjuvant, essentially as previously reported for proteins I and $\mathrm{II}^{*}$ of $E$. coli $026 \mathrm{~K} 60$ (Hofstra \& Dankert, 1980a). Absorption of the antisera with LPS O26 was carried out by repeated addition of small amounts of the antigen from a $10 \mathrm{mg} \mathrm{ml}^{-1}$ solution in phosphate-buffered saline (PBS, pH 7.2), each addition being followed by incubation $\left(30 \mathrm{~min}, 37^{\circ} \mathrm{C}\right)$ and centrifugation $(15000 \mathrm{~g}, 10 \mathrm{~min})$. Absorption was continued until no visible immunoprecipitates were formed. Antibodies against lipoprotein were absorbed from the sera by direct addition of a large excess of lyophilized murein-lipoprotein complex labout $10 \mathrm{mg}(\mathrm{ml} \mathrm{serum})^{-1}$, followed by incubation at $37^{\circ} \mathrm{C}$ for $1 \mathrm{~h}$ and subsequently at $4{ }^{\circ} \mathrm{C}$ overnight. Murein-lipoprotein and absorbed 
antibodies were removed from the sera by filtration $(0.02 \mu \mathrm{m}$ Millipore filter). To test the reaction of antibodies against porin oligomers and porin monomers with intact $\mathrm{OM}$ of $E$. coli $\mathrm{O} 26 \mathrm{~K} 60$, antisera (diluted $1: 2,1: 20$ or $1: 80$ with PBS) were absorbed with lyophilized OM-peptidoglycan complex $\left[5 \mathrm{mg}\right.$ (ml serum) $\left.{ }^{-1}\right]$. Absorptions were done at $37^{\circ} \mathrm{C}$ for $1 \mathrm{~h}$ followed by incubation at $4{ }^{\circ} \mathrm{C}$ overnight. $\mathrm{OM}$ and absorbed antibodies were removed by filtration ( $0.2 \mu \mathrm{m}$ Millipore filter).

Enzyme-linked immunosorbent assay (ELISA). ELISA was carried out in microtitre trays (M-24 AR; Greiner, Nürtingen, F.R.G.) coated wtih porin monomers, porin oligomers, oligomers heated at $100^{\circ} \mathrm{C}$ for $5 \mathrm{~min}$ in SDS-containing buffer, LPS O26 or free lipoprotein. The assay was performed as previously described (Hofstra \& Dankert, 1980a).

SDS-polyacrylamide gel immunoperoxidase technique (SGIP). The first step in this procedure was SDS-PAGE on $11 \%(\mathrm{w} / \mathrm{v})$ acrylamide slab gels (thickness $1.2 \mathrm{~mm})$. The discontinuous buffer system described by Laemmli (1970) was used without modification. Molecular weight standards were the same as used previously (Dankert \& Hofstra, 1978). Samples (porin monomers or oligomers) were heated at $100^{\circ} \mathrm{C}$ for 5 min in sample buffer (Laemmli, 1970) or dispersed by sonication in this buffer at $37^{\circ} \mathrm{C}$ (porin oligomers). About $20 \mu \mathrm{l}$ of these samples, containing 15-20 $\mu \mathrm{g}$ protein, were applied to each gel slot. Elctrophoresis was carried out at $25 \mathrm{~mA}$ until the bromophenol blue tracking dye had moved $4 \mathrm{~cm}$ into the separating gel. The SGIP technique was performed as described previously (Hofstra \& Dankert, $1980 \mathrm{c}$ ).

Double immunodiffusion. Double immunodiffusion (Ouchterlony, 1958) was performed in $0.5 \%(\mathrm{w} / \mathrm{v}$ ) agarose (Hoechst, Frankfurt, F.R.G.) in PBS ( $\mathrm{pH} \mathrm{7.2)} \mathrm{containing} 0.05 \%(\mathrm{w} / \mathrm{v})$ SDS. Antigens were dispersed by sonication to a concentration of $0.2 \mathrm{mg} \mathrm{ml}^{-1}$ in PBS containing $0.05 \%(w / v)$ SDS at room temperature (porin monomers, porin oligomers, free lipoprotein, lipopolysaccharide and murein-lipoprotein); in addition, porin oligomers were dispersed at $100{ }^{\circ} \mathrm{C}$. Peripheral wells were filled with $20 \mu$ samples of the antigen suspensions; the centre well was filled with $20 \mu \mathrm{l}$ of antiserum [diluted $1: 2$ in PBS containing $0.05 \%(\mathrm{w} / \mathrm{v})$ SDS|. Diffusion was allowed to proceed for $24 \mathrm{~h}$ at room temperature. Washing, drying and staining of the agarose plates were done as described previously (Hofstra \& Dankert, 1980a).

\section{RESULTS}

$S D S$-polyacrylamide gel immunoperoxidase technique (SGIP)

Sections $(40 \mu \mathrm{m}$ thick) were prepared from SDS-PAGE gels after separation of porin oligomers dispersed in sample buffer at $37^{\circ} \mathrm{C}$, oligomers solubilized in the same buffer by heating at $100^{\circ} \mathrm{C}$ for $5 \mathrm{~min}$ and purified porin monomers solubilized by boiling in sample buffer; these were treated with different antisera following the SGIP technique. Application of the specific antiserum against native porin oligomers (LPS-absorbed) resulted in the SGIP profiles shown in Fig. 1, section 1. In the profile of the native porin (section $1 a$ ) two bands were stained with apparent molecular weights of approximately 100000 and 70000 . The 100000 molecular weight band corresponds to the trimer form of the porin protein (Palva \& Randall, 1978) while the 70000 molecular weight band probably represents porin dimers. Porin monomers (molecular weight 36000 ) were not stained in the profile of the native porin (section $1 a$ ) but reacted very weakly in the profiles of boiled porin (section $1 b$ ) and chromatographically purified porin monomers (section $1 c$ ). Material present in the dye front of SDS-PAGE in all three tracks gave a weakly positive reaction. When gel sections were treated with anti-porin oligomer serum that had been absorbed with both LPS and murein-lipoprotein, the reaction of the material moving with the dye front was weaker (Fig. 1 , section 2). The reactions of porin trimers and dimers were not affected by this absorption. This indicates that the material moving with the dye front of SDS-PAGE consisted at least partly of lipoprotein (molecular weight 7600 ) apparently present in our porin preparations. Furthermore, it shows that antibodies against lipoprotein were present in our anti-porin oligomer serum. When antiserum against porin monomers (LPS-absorbed) was used, the monomers present in the profiles of the boiled porin and of the chromatographically purified porin monomers were heavily stained (Fig. 1, section $3 b$ and $c$ ). Also the small amount of monomer present in the profile of the native porin preparation reacted positively with this serum (section $3 a$ ). In addition, there was a very weak reaction of the porin oligomer bands in this track. The positive reaction of the material present in the dye front was weaker after an additional absorption of the anti-monomer serum with murein-lipoprotein (Fig. 1, section 4). 


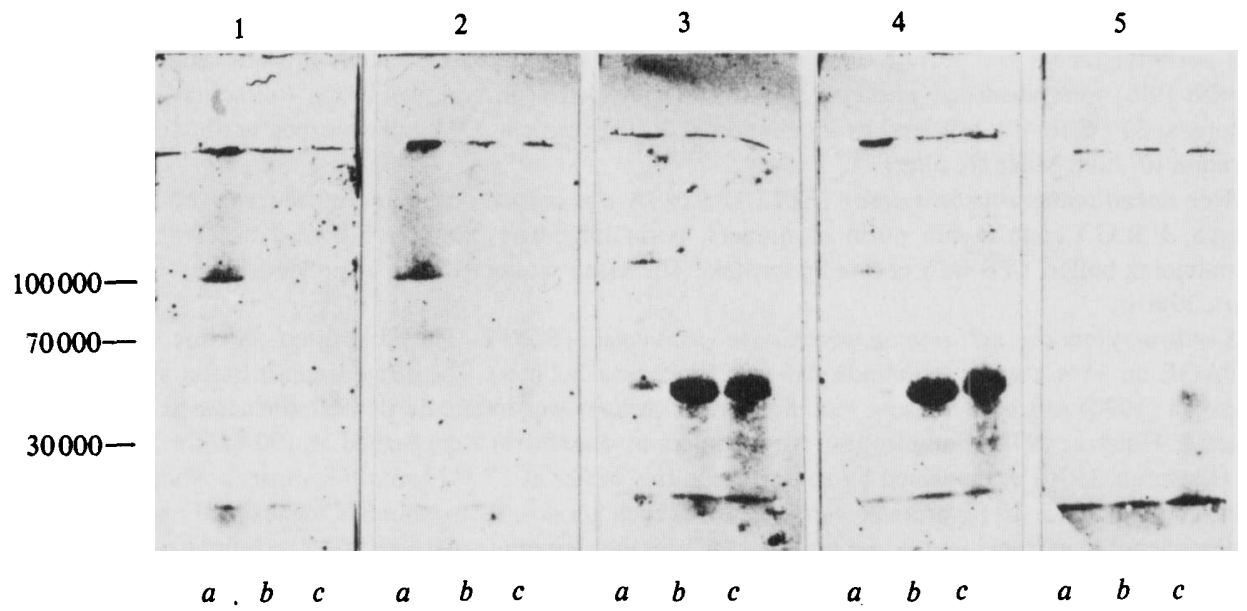

Fig. 1. SDS-polyacrylamide gel immunoperoxidase (SGIP) analysis of preparations isolated from the outer membrane of $E$. coli $\mathrm{O} 26 \mathrm{~K} 60$. Porin oligomers isolated and purified in the native configuration were dispersed in SDS-containing sample buffer at $37^{\circ} \mathrm{C}(a)$ or heated at $100^{\circ} \mathrm{C}$ for 5 min in the same buffer $(b)$; porin monomers isolated and purified under denaturing conditions were solubilized by heating at $100^{\circ} \mathrm{C}$ in sample buffer $(c)$. Samples were subjected to SDS-PAGE according to Laemmli (1970) and subsequently the unstained gel was sliced into $40 \mu \mathrm{m}$ thick sections, each containing the electrophoretic profiles of the three porin preparations. Sections were treated in the SGIP technique with the following antisera (all previously absorbed with LPS O26): (1) antiserum against native porin oligomers; (2) the same antiserum after absorption with murein-lipoprotein complex; (3) antiserum against denatured porin monomers; (4) the same antiserum after absorption with murein-lipoprotein; (5) antiserum against murein-lipoprotein. Molecular weights are indicated on the left.
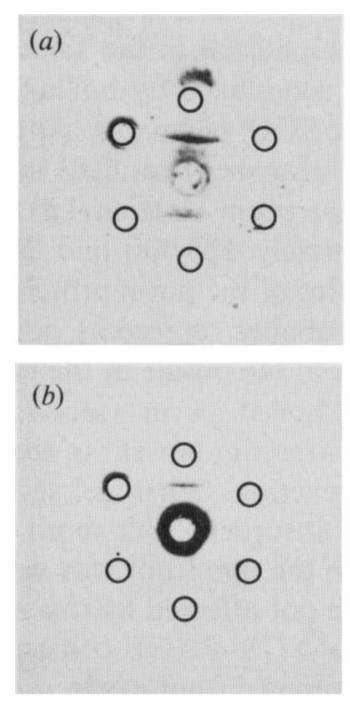
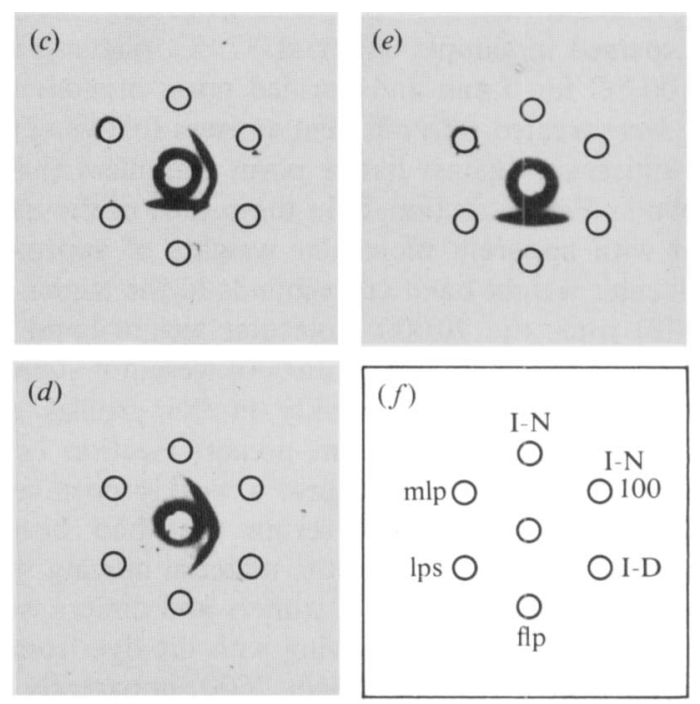

Fig. 2. Immunodiffusion in $0.5 \%(w / v)$ agarose in PBS (pH 7.2) containing $0.05 \%(w / v)$ SDS. Antigens were dispersed to a concentration of $0.2 \mathrm{mg} \mathrm{m}^{-1}$ in PBS containing $0.05 \%(\mathrm{w} / \mathrm{v})$ SDS. Peripheral wells were filled with $20 \mu \mathrm{l}$ of the antigen suspensions as indicated in $(f): \mathrm{I}-\mathrm{N}$, native porin oligomers, dispersed in PBS/SDS at room temperature; I-N 100, oligomers dispersed in PBS/SDS at $100^{\circ} \mathrm{C}$; I-D, purified denatured porin monomers; flp, free lipoprotein; Ips, lipopolysaccharide $\mathrm{O} 26$; mlp, murein-bound lipoprotein. Centre wells were filled with $20 \mu \mathrm{l}$ of antiserum (previously absorbed with LPS O26) diluted 1:2 with PBS/SDS: (a) antiserum against native porin oligomers; $(b)$ the same antiserum after absorption with murein-lipoprotein; $(c)$ antiserum against denatured porin monomers; $(d)$ the same antiserum absorbed with murein-lipoprotein; $(e)$ antiserum against murein-lipoprotein. Diffusion was allowed to proceed for $24 \mathrm{~h}$ before the plates were washed, dried and stained. 
Table 1. Quantitative determination of antibody titres by the enzyme-linked immunosorbent assay (ELISA)

Antisera against native porin oligomers and against denatured porin monomers derived from the OM of $E$. coli $\mathrm{O} 26 \mathrm{~K} 60$ were elicited by intramuscular administration to rabbits. ELISA was carried out on microtitre trays coated with suspensions of different antigens at $30 \mu \mathrm{g} \mathrm{m}^{-1}$ in $0.1 \mathrm{M}-\mathrm{Na}_{2} \mathrm{CO}_{3}$ ( $\mathrm{pH}$ 9.6). Sera were diluted with PBS (pH 7.2) containing $1 \%(\mathrm{w} / \mathrm{v})$ bovine serum albumin and $0.05 \%(w / v)$ Tween 20 . The second incubation was performed with horseradish peroxidase-conjugated goat anti-rabbit IgG, diluted 1:1250. 5-Aminosalicylic acid was used as peroxidase substrate. Titres are given as the reciprocal of the highest serum dilution showing a positive colour development after $30 \mathrm{~min}$ at room temperature.

\begin{tabular}{|c|c|c|c|c|c|c|}
\hline \multirow{2}{*}{\multicolumn{2}{|c|}{ Antiserum }} & \multicolumn{5}{|c|}{ 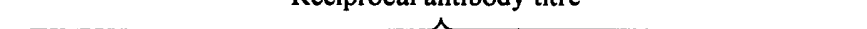 } \\
\hline & & Native & Native porin & Denatured & & \\
\hline $\begin{array}{l}\text { Elicited } \\
\text { against: }\end{array}$ & $\begin{array}{l}\text { Absorbed } \\
\text { with: }\end{array}$ & $\begin{array}{c}\text { porin } \\
\text { oligomers }\end{array}$ & $\begin{array}{l}\text { oligomers heated } \\
\text { at } 100^{\circ} \mathrm{C}\end{array}$ & $\begin{array}{l}\text { porin } \\
\text { monomers }\end{array}$ & LPS O26 & $\begin{array}{c}\text { Free } \\
\text { lipoprotein }\end{array}$ \\
\hline $\begin{array}{l}\text { Native porin } \\
\text { oligomers }\end{array}$ & - & 5120 & 160 & 160 & 320 & 640 \\
\hline $\begin{array}{l}\text { Native porin } \\
\text { oligomers }\end{array}$ & $\begin{array}{l}\text { LPS O26 and } \\
\text { murein- } \\
\text { lipoprotein }\end{array}$ & 5120 & 160 & 160 & $<20$ & 80 \\
\hline $\begin{array}{l}\text { Denatured } \\
\text { porin monomers }\end{array}$ & - & 10000 & 20000 & 20000 & 320 & 2560 \\
\hline $\begin{array}{l}\text { Denatured } \\
\text { porin monomers }\end{array}$ & $\begin{array}{l}\text { LPS O26 and } \\
\text { murein- } \\
\text { lipoprotein }\end{array}$ & $5120-10000$ & 20000 & 20000 & $<20$ & $80-160$ \\
\hline
\end{tabular}

When a section was treated with antiserum against murein-lipoprotein (LPS-absorbed) a strong reaction was observed in the dye front in all tracks (Fig. 1, section 5), while there was no significant reaction with any of the porin components.

\section{Specificity of antisera in immunodiffusion}

The LPS-absorbed antiserum prepared against native porin gave a single precipitin line with the corresponding antigen (dispersed at room temperature) in agarose immunodiffusion and a weak line with free lipoprotein (Fig. $2 a$ ). No reaction was observed with boiled porin, purified porin monomers, LPS or murein-lipoprotein complex. Absorption of this antiserum with murein-lipoprotein complex resulted in the disappearance of the precipitin line formed with free lipoprotein, while the line formed with native porin was unaffected (Fig. $2 b$ ). The antiserum against denatured porin monomers (LPS-absorbed) gave immunoprecipitates with boiled porin and with purified porin monomers which reacted as identical antigens (Fig. $2 c$ ). In addition, a precipitin line was formed with free lipoprotein, but the reaction was non-identical to that with porin monomers. This line was not seen after an additional absorption of the antiserum with murein-lipoprotein (Fig. $2 d$ ). The line formed with boiled porin curved slightly towards native porin without forming a visible precipitate with this preparation (Fig. $2 c, d$ ). This indicates the presence of a small amount of material in our native porin preparation that is identical with boiled porin and purified porin monomers, although the native porin itself did not react with anti-monomer serum. The antiserum against the murein-lipoprotein complex gave a precipitin line with free lipoprotein (Fig. $2 e$ ) while no precipitation occurred with the murein-lipoprotein complex itself. This indicates that antibodies elicited against the murein-bound lipoprotein reacted with the free form of this outer membrane component and that the murein-lipoprotein complex itself was apparently not able to diffuse into the agarose.

\section{Quantitative determination of specific antibodies by ELISA}

Antisera against native porin oligomers or purified denatured porin monomers showed high antibody titres against their specific antigens in ELISA (Table 1). In addition, both sera contained a moderate amount of antibodies against LPS and free lipoprotein which could be 


\section{Table 2. Absorption of antibodies against native porin oligomers and denatured porin monomers by $O M$-peptidoglycan complex}

Antisera against native porin oligomers and against denatured porin monomers derived from the OM of $E$. coli $\mathrm{O} 26 \mathrm{~K} 60$ were elicited by intramuscular administration to rabbits, and then absorbed with LPS 026 and murein-lipoprotein. Where indicated, they were then diluted $1: 2$, 1:20 or $1: 80$ with PBS ( $\mathrm{pH} \mathrm{7.2)} \mathrm{and} \mathrm{incubated} \mathrm{with} \mathrm{lyophilized} \mathrm{OM-peptidoglycan} \mathrm{complex} \mathrm{of} \mathrm{E.} \mathrm{coli} \mathrm{O26} \mathrm{K60}$ $\left(5 \mathrm{mg} \mathrm{ml}^{-1}\right.$ ) at $37^{\circ} \mathrm{C}$ for $1 \mathrm{~h}$ followed by $4^{\circ} \mathrm{C}$ overnight. $\mathrm{OM}$ and absorbed antibodies were removed by filtration ( $0.2 \mu \mathrm{m}$ Millipore filter). ELISA was carried out as described in the legend to Table 1 .

\begin{tabular}{|c|c|c|c|}
\hline \multicolumn{2}{|c|}{ Antiserum } & \multicolumn{2}{|c|}{ Reciprocal antibody titre } \\
\hline $\begin{array}{l}\text { Elicited } \\
\text { against: }\end{array}$ & $\begin{array}{l}\text { Serum dilution } \\
\text { for absorption }\end{array}$ & $\begin{array}{c}\text { Native } \\
\text { porin oligomers }\end{array}$ & $\begin{array}{c}\text { Denatured } \\
\text { porin monomers }\end{array}$ \\
\hline Native porin oligomers & $\begin{array}{l}\text { Neat, unabsorbed } \\
\begin{array}{l}1: 2 \\
1: 20 \\
1: 80\end{array}\end{array}$ & $\begin{array}{r}5120 \\
80 \\
20 \\
80\end{array}$ & $\begin{array}{r}160 \\
80 \\
80 \\
80\end{array}$ \\
\hline Denatured porin monomers & $\begin{array}{l}\text { Neat, unabsorbed } \\
1: 2 \\
1: 20 \\
1: 80\end{array}$ & $\begin{array}{r}10000 \\
5120 \\
5120 \\
5120\end{array}$ & $\begin{array}{l}20000 \\
20000 \\
10000 \\
10000\end{array}$ \\
\hline
\end{tabular}

removed by absorption with the appropriate antigens. Anti-native porin serum had an insignificant titre against denatured monomers. However, the anti-monomer serum showed a high titre against the native oligomers. Although this titre was comparable with that against denatured monomers, colour development was very weak throughout all serum dilutions. This probably indicates the presence of a small amount of denatured porin monomer in the native porin preparation used for ELISA, which is consistent with the observations made by immunodiffusion.

\section{Absorption of antibodies to the intact $O M$}

Antisera against native porin or denatured porin monomers (absorbed with LPS and murein-lipoprotein) were additionally absorbed with OM-peptidoglycan complex of $E$. coli $026 \mathrm{~K} 60$ at $5 \mathrm{mg} \mathrm{ml}^{-1}$, the serum being diluted $1: 2,1: 20$ or $1: 80$ with PBS. Quantitative determination of antibody titres by ELISA showed that antibodies against the native porin oligomers were completely removed by the absorption to the intact OM (Table 2). Antibodies against denatured monomers were not absorbed. Also, the apparent low affinity titre of the antiserum against porin monomers observed on trays coated with native porin was not affected by the absorption. Thus, this titre was not caused by antibodies able to react with the native porin situated in the intact $\mathrm{OM}$ structure.

\section{DISCUSSION}

Our results indicate that native oligomers and denatured monomers of the major porin of $E$. coli differ greatly in their immunological properties. The antiserum elicited against native porin oligomers reacted with this material in all experiments, but showed no significant reaction with porin monomers. This indicates that intramuscular administration of native porin to rabbits gave rise to an antibody response exclusively directed against antigenic determinants which are lost on dissociation of the oligomers by heating in SDS solution. The antibodies against porin oligomers were removed on absorption with intact OMpeptidoglycan complex indicating that they were directed against those portions of the porin oligomer which are exposed on the surface of the OM.

On the other hand, antibodies elicited against denatured porin monomers reacted strongly with the corresponding antigen and also reacted to a small extent with native porin oligomers in the very sensitive SGIP technique. Absorption with intact OM did not reduce the antibody activity of the anti-monomer serum. These observations indicate that the major antigenic 
determinants of the denatured porin monomer show hardly any relationship to those of the native porin situated in the intact $\mathrm{OM}$, and that they become fully expressed only after dissociation and denaturation of the porin oligomer.

We conclude that native porin oligomers and denatured monomers differ markedly in their antigenic structure and behave like practically unrelated antigens.

All our data are consistent with the presence of a small amount of denatured monomers in the native porin preparation. This contamination was apparently too low to be detected on polyacrylamide gels stained with Coomassie Brilliant Blue or to evoke a significant anti-monomer response after administration of the native porin to rabbits. However, it was high enough to influence the results of immunodiffusion and ELISA and to be detected on SGIP profiles when the native porin preparation was reacted with anti-monomer serum in these techniques. In addition to these monomers the SGIP technique also revealed the presence of porin dimers in our native porin preparation. It is interesting that the monomers reacted only with the antiserum against denatured monomers, while the dimers reacted in the same way as the native porin trimer. Native porin trimers are very rich in $\beta$-structure which changes immediately to an $\alpha$-helix on dissociation by heating in SDS (Nakamura \& Mizushima, 1976; Nakae et al., 1979). Native porin monomers (rich in $\beta$-structure) can be obtained by electrodialysis in the presence of Triton X-100 (Nakae et al., 1979; Tokunaga et al., 1979), but they assume an $\alpha$-helical conformation immediately on exposure to SDS. The results of our SGIP experiments confirm this apparent instability of the porin monomer, whereas they indicate that the porin dimer is stable in SDS solution and retains its native configuration.

In studies using the SGIP technique (Hofstra \& Dankert, $1980 b, c$ ) or crossed immunoelectrophoresis (Hofstra et al., 1980), we found that heat and SDS-dissociated porin monomers from many species of Enterobacteriaceae cross-reacted antigenically. Also, the heat and SDS-inactivated porin monomers originating from different pore proteins of $E$. coli $\mathrm{K} 12$ (e, ompF protein or $\mathrm{b}$, and ompC protein or c) have been shown to be cross-reactive (Overbeeke et al., 1980). However, the results of the present study indicate that the native porin oligomers and the heat-dissociated monomers derived from the same pore protein share no important antigenic determinants. Therefore, the question of whether the native trimers of the different pore proteins found on a single strain or on different enterobacterial strains and species are immunologically related remains unanswered. The possible immunological relationship of the native porins isolated from various strains of $E$. coli and other Enterobacteriaceae are presently under investigation.

In comparison with the peptidoglycan-bound protein I (porin) described in this study, the non-peptidoglycan-bound, heat-modifiable major OM protein II* appears to be more stable in its antigenic structure. We found that the heat-modified and the unmodified forms of this protein reacted as identical antigens with antiserum elicited against unmodified (native) protein II* (Van Tol et al., 1979; Hofstra et al., 1980). Therefore, in a strictly immunological sense, protein I (porin) rather than protein $\mathrm{II}^{*}$ should be considered to be the 'heat-modifiable' major OM protein.

We are grateful to Mr R. W. Rozeboom for his skilful technical assistance and to Miss M. ten Kate for typing this manuscript.

\section{REFERENCES}

Benz, R., Janko, K., Boos, W. \& Laüger, P. (1978). Formation of large, ion-permeable membrane channels by the matrix protein (porin) of Escherichia coli. Biochimica et biophysica acta 511, 305-319.

DANKert, J. \& Hofstra, H. (1978). Antibodies against outer membrane proteins in rabbit antisera prepared against Escherichia coli O26 K60. Journal of General Microbiology 104, 311-320.
Datta, D. B., Arden, B. \& Henning, U. (1977). Major proteins of the Escherichia coli outer cell envelope membrane as bacteriophage receptors. Journal of Bacteriology 131, 821-829.

Decad, G. M. \& Nikaido, H. (1976). Outer membrane of Gram-negative bacteria. XII. Molecular sieving function of cell wall. Journal of Bacteriology 128, 325-336. 
Hasegawa, Y., Yamada, H. \& Mizushima, S. (1976). Interactions of outer membrane proteins $0-8$ and O-9 with peptidoglycan sacculus of Escherichia coli K-12. Journal of Biochemistry 80, 1401-1409.

Hofstra, H. \& DANKerT, J. (1979). Antigenic cross-reactivity of major outer membrane proteins in Enterobacteriaceae species. Journal of General Microbiology 111, 293-302.

Hofstra, H. \& DANKerT, J. (1980a). Preparation and quantitative determination of antibodies against major outer membrane proteins of Escherichia coli 026 K60. Journal of General Microbiology 117, 437-447.

Hofstra, H. \& DANKerT, J. (1980 b). Antigenic cross-reactivity of outer membrane proteins of Escherichia coli and Proteus species. FEMS Microbiology Letters 7, 171-174.

Hofstra, H. \& DaNkERT, J. (1980c). Major outer membrane proteins: common antigens in Enterobacteriaceae species. Journal of General Microbio$\log y 119,123-131$.

Hofstra, H., Van Tol, M. J. D. \& Dankert, J. (1980). Antigenic cross-reactivity of the major outer membrane proteins of Enterobacteriaceae studied by crossed immunoelectrophoresis. Journal of Bacterio$\log y$ 143, 328-337.

InOUYe, S., TAKeIShI, K., LeE, N., DeMaRTINI, M., HARAShima, A. \& INOUYE, M. (1976). Lipoprotein from the outer membrane of Escherichia coli: purification, paracrystallization and some properties of its free form. Journal of Bacteriology 127, 555-563.

LAEMMLI, U. K. (1970). Cleavage of structural proteins during the assembly of the head of bacteriophage T4. Nature, London 227, 680-685.

Lugtenberg, B., Meljers, J., Peters, R., Van der Hoek, P. \& Van Alphen, L. (1975). Electrophoretic resolution of the 'Major outer membrane protein' of Escherichia coli $\mathrm{K} 12$ into four bands. FEBS Letters 58, 254-258.

NAKAE, T. (1976a). Identification of the outer membrane protein of Escherichia coli that produces transmembrane channels in reconstituted vesicle membranes. Biochemical and Biophysical Research Communications 71, 877-884.

NAKAE, T. (1976b). Outer membrane of Salmonella. Isolation of protein complex that produces transmembrane channels. Journal of Biological Chemistry 251, 2176-2178.

NAKAE, T. \& Nikaido, H. (1975). Outer membrane as a diffusion barrier in Salmonella typhimurium: penetration of oligo- and polysaccharides into isolated outer membrane vesicles and cells with degraded peptidoglycan layer. Journal of Biological Chemistry 250, 7359-7365.

NakaE, T., IshII, J. \& Tokunaga, M. (1979). Subunit structure of functional porin oligomers that form permeability channels in the outer membrane of Escherichia coli. Journal of Biological Chemistry 254, 1457-1461.

Nakamura, K. \& Mizushima, S. (1976). Effects of heating in dodecyl sulphate solution on the conformation and electrophoretic mobility of isolated major outer membrane proteins from Escherichia coli K-12. Journal of Biochemistry 80, 1411-1422.

OUCHTERLONY, Ö. (1958). Diffusion-in-gel methods for immunological analysis. In Progress in Allergy, vol. 5, pp. 1-78. Edited by P. Kallós. Basel: S. Karger.

OVerbeeke, N., Van Scharrenburg, G. \& LUGTENBERG, B. (1980). Antigenic relationship between pore proteins of Escherichia coli K12. European Journal of Biochemistry 110, 247-254.

Palva, E. T. \& Randall, L. L. (1978). Arrangement of protein I in Escherichia coli outer membrane: cross-linking study. Journal of Bacteriology 133, 279-286.

RosenbusCh, J. P. (1974). Characterization of the major envelope protein from Escherichia coli. Regular arrangement on the peptidoglycan and unusual dodecyl sulfate binding. Journal of Biological Chemistry 249, 8019-8029.

Schnartman, C. A. (1971). Solubilization of the cytoplasmic membrane of Escherichia coli by Triton X-100. Journal of Bacteriology 108, 545-552.

Tokunaga, M., Tokunaga, H., OKaJima, Y. \& NAKAE, T. (1979). Characterization of porins from the outer membrane of Salmonella typhimurium. 2. Physical properties of the functional oligomeric aggregates. European Journal of Biochemistry 95, 441-448.

VAN TOL, M. J. D., Hofstra, H. \& Dankert, J. (1979). Major outer membrane proteins of Escherichia coli analysed by crossed immunoelectrophoresis. FEMS Microbiology Letters 5, 349-352.

Verhoef, C., DE GRAaFF, P. J. \& Lugtenberg, E. J. J. (1977). Mapping of a gene for a major outer membrane protein of Escherichia coli $\mathrm{K} 12$ with the aid of a newly isolated bacteriophage. Molecular and General Genetics 150, 103-105. 